\title{
Applications of Photocatalytic Disinfection
}

\author{
Joanne Gamage and Zisheng Zhang \\ Department of Chemical and Biological Engineering, University of Ottawa, 161 Louis Pasteur, Ottawa, ON, Canada K1N6N5
}

Correspondence should be addressed to Zisheng Zhang, jason.zhang@uottawa.ca

Received 28 June 2010; Accepted 11 August 2010

Academic Editor: Detlef W. Bahnemann

Copyright ( $) 2010$ J. Gamage and Z. Zhang. This is an open access article distributed under the Creative Commons Attribution License, which permits unrestricted use, distribution, and reproduction in any medium, provided the original work is properly cited.

\begin{abstract}
Due to the superior ability of photocatalysis to inactivate a wide range of harmful microorganisms, it is being examined as a viable alternative to traditional disinfection methods such as chlorination, which can produce harmful byproducts. Photocatalysis is a versatile and effective process that can be adapted for use in many applications for disinfection in both air and water matrices. Additionally, photocatalytic surfaces are being developed and tested for use in the context of "self-disinfecting" materials. Studies on the photocatalytic technique for disinfection demonstrate this process to have potential for widespread applications in indoor air and environmental health, biological, and medical applications, laboratory and hospital applications, pharmaceutical and food industry, plant protection applications, wastewater and effluents treatment, and drinking water disinfection. Studies on photocatalytic disinfection using a variety of techniques and test organisms are reviewed, with an emphasis on the end-use application of developed technologies and methods.
\end{abstract}

\section{Introduction}

Applications of photocatalytic processes are widely recognized as viable solutions to environmental problems [1-3]. Disinfection of bacteria is of particular importance, because traditional methods such as chlorination are chemical intensive and have many associated disadvantages. For example, in water treatment applications, chlorine used for disinfection can react with organic material to generate chloro-organic compounds that are highly carcinogenic $[4,5]$. Furthermore, some pathogens such as viruses, certain bacteria such as Legionella, and protozoans such as Cryptosporidium and Giardia lamblia cysts have been known to be resistant to chlorine disinfection [6,7]. Other treatment alternatives such as ozonation and irradiation using germicidal lamps (254 nm) have their own problems and limitations, such as the lack of residual effect [8] and generation of small colony variants [9] for the latter and production of toxic disinfection byproducts for the former [10].

In comparison, the $\mathrm{TiO}_{2}$ semiconductor commonly used in photocatalytic processes is nontoxic, chemically stable, available at a reasonable cost, and capable of repeated use without substantial loss of catalytic ability [11]. Heterogeneous photocatalysis using titanium dioxide is a safe, nonhazardous, and ecofriendly process which does not produce any harmful byproducts. Extensive research in this field has been done in the area of photocatalytic removal of organic, inorganic, and microbial pollutants $[12,13]$.

The mechanism of bactericidal action of $\mathrm{TiO}_{2}$ photocatalysis, as reported by Sunada et al. is attributed to the combination of cell membrane damage and further oxidative attack of internal cellular components, ultimately resulting in cell death [14].

Since the breakthrough work of Matsunaga et al. in 1985 reporting the application of $\mathrm{TiO}_{2}$ photocatalysis for the destruction of Lactobacillus acidophilus, Saccharomyces cerevisiae, and Escherichia coli using platinum-loaded $\mathrm{TiO}_{2}$ [15], there has been much interest in the biological applications of this process. A very comprehensive review of the application of $\mathrm{TiO}_{2}$ photocatalysis for disinfection of water is given by Mccullagh et al. [16], with many others available in the literature [17-21].

Research in the field of photocatalytic disinfection has been very diverse, with the $\mathrm{TiO}_{2} / \mathrm{UV}$ process being shown to successfully inactivate many microorganisms including bacteria such as E. coli [22-24], L. acidophilus [15], Serratia domonas stutzeri [25], Bacillus pumilus [26], Streptococcus mutans [1], yeasts such as S. cerevisiae [15], algae such 
as Chlorella vulgaris [15], and viruses such as phage MS2 $[15,27,28]$, B. fragilis bacteriophage [15, 27], Poliovirus I [28], Cryptosporidium parvum [29], and Giardia intestinalis [30].

Research efforts are being made to improve the efficiency of the $\mathrm{TiO}_{2}$ catalyst by means of doping with various metals [31-33] and nonmetals [34, 35]. Other parameters which can be varied in a photocatalytic process, such as the source of ultraviolet irradiation [18] and factors affecting process efficiency [36] have also been under investigation. Additionally, there are countless reactor designs and configurations $[37,38]$ used to exploit photocatalytic disinfection for a wide range of applications, as this process can be used in both water and air matrices [39]. The current review will focus on developments in photocatalytic disinfection for application in the following contexts: indoor air and environmental health, biological and medical applications, laboratory and hospital applications, pharmaceutical and food industry, plant protection applications, wastewater and effluents treatment, and finally, drinking water disinfection.

\section{Indoor Air and Environmental Health}

The photocatalytic process is well recognized for the removal of organic pollutants in the gaseous phase such as volatile organic compounds (VOCs), having great potential applications to contaminant control in indoor environments such as residences, office buildings, factories, aircrafts, and spacecrafts $[40,41]$.

To increase the scope of the photocatalytic process in application to indoor air, the disinfection capabilities of this technique are under investigation [39]. Disinfection is of importance in indoor air applications because of the risk of exposure to harmful airborne contaminants. Bioaerosols are a major contributor to indoor air pollution, and more than 60 bacteria, viruses, and fungi are documented as infectious airborne pathogens. Diseases transmitted via bioaerosols include tuberculosis, Legionaries, influenza, colds, mumps, measles, rubella, small pox, aspergillosis, pneumonia, meningitis, diphtheria, and scarlet fever [42]. Traditional technologies to clean indoor air include the use of activated charcoal filters, HEPA filters, ozonation, air ionization, and bioguard filters. None of these technologies is completely effective [20].

In the pioneering work by Goswami et al. [43, 44] investigating the disinfection of indoor air by photocatalysis, a recirculating duct facility was developed to inactivate biological contaminants in air with photocatalytic techniques. Experiments using Serratia Marcescens in air achieved a $100 \%$ destruction of microorganisms in a recirculating loop in 600 minutes [43]. This time was reduced to less than 3 minutes in later experiments [45].

Photocatalytic oxidation can also inactivate infectious microorganisms which can be airborne bioterrorism weapons, such as Bacillus anthracis (Anthrax) [46-48]. A photocatalytic system was investigated by Knight in 2003 to reduce the spread of severe acute respiratory syndrome (SARS) on flights [49], following the outbreak of the disease.
Similarly, in 2007 the avian influenza virus A/H5N2 was shown to be inactivated from the gaseous phase using a photocatalytic prototype system [39].

Inactivation of various gram-positive and gram-negative bacteria using visible light and a doped catalyst [50] and fluorescent light irradiation similar to that used in indoor environments was studied [51] and shows great promise for widespread applications.

It was also shown that $E$. coli could be completely mineralized on a $\mathrm{TiO}_{2}$ coated surface in air [42]. Carbon mass balance and kinetic data for complete oxidation of $E$. coli, A. niger, Micrococcus luteus, and B. subtillus cells and spores were subsequently presented [52]. A comprehensive mechanism and detailed description of the $\mathrm{TiO}_{2}$ photokilling of $E$. coli on coated surfaces in air has been extensively studied in order understand to a considerable degree and in a quantitative way the kinetics of E. coli immobilization and abatement using photocatalysis, using FTIR, AFM, and CFU as a function of time and peroxidation of the membrane cell walls [53-57].

Novel photoreactors and photo-assisted catalytic systems for air disinfection applications such as those using polyester supports for the catalyst [58], carbon nanotubes [59], combination with other disinfection systems [60], membrane systems [61], use of silver bactericidal agents in cotton textiles [62-64] for the abatement of E. coli in air, high surface area $\mathrm{CuO}$ catalysts [65], and structure silica surfaces [66] have also been reported.

In terms of environmental health, the antifungal capability of $\mathrm{TiO}_{2}$ photocatalysis against mold fungi on coated wood boards used in buildings was confirmed [67] using A. nigeras a test microbe, and UVA irradiation.

\section{Biological and Medical Applications}

Due to the disinfection abilities of photocatalytic processes, they are being explored for use in medical applications. Studies have been done using $\mathrm{TiO}_{2}$ coatings on bioimplants to implement photocatalysis for antibacterial purposes [47, $68,69]$. Shiraishi et al. explored the photocatalytic activity of $S$. aureus, a common pathogenic bacterium in implantrelated infection, using $\mathrm{TiO}_{2}$ film on stainless steel and titanium substrates [70]. The bactericidal effect of the coating was confirmed upon UV irradiation, and the use of these coated photocatalytic substrates present a useful strategy for the control of such infections associated with biomedical implants.

Photocatalysis is also able to kill animal cells, such as in the antitumor activity shown using subcutaneous titania injection onto skin tumours followed by 40 minutes of UV illumination [71]. This procedure produced a tenfold tumour volume reduction after three weeks, where the catalyst and light alone control runs showed tumor increases in volume by factors of 30-50. The use of photocatalysis for cancer cell treatment has also been documented elsewhere $[1,72]$.

As previously alluded to in air-disinfection strategies, photocatalysis can be employed to remove harmful airborne 
biological threats such as Anthrax $[48,73]$. In this sense, it can be an effective technique for combating bioterror and preventing the spread of airborne biological threats.

\section{Laboratory and Hospital Applications}

Particularly in microbiological laboratories and in areas in intensive medical use, frequent and thorough disinfection of surfaces is needed in order to reduce the concentration of bacteria and to prevent bacterial transmission. Conventional methods of disinfection with wiping are not long-term effective, and are staff and time intensive. These methods also involve the use of harsh and aggressive chemicals. Disinfection with hard ultraviolet light (UVC) is usually unsatisfactory, since the depth of penetration is inadequate and there are occupational health risks [74].

Photocatalytic oxidation on surfaces coated with titanium dioxide offers an alternative to traditional methods of surface disinfection. Research has examined the biocidal activity of thin films of titania anchored to solid surfaces [7476]. The effectiveness of this process was demonstrated using bacteria relevant to hygiene such as E. coli, p. aeruginosa, S. aureus, and E. faecium [74]. The inactivation of E. coli (ATCC8739) cells deposited on membrane filters during irradiation with fluorescent light was also shown as an application of self-disinfecting surfaces [77].

$\mathrm{TiO}_{2}$ thin films deposited on stainless steel using a novel flame-assisted CVD technique were also tested for antimicrobial activity on E. coli [69]. There is a wider range of applications for this self-disinfecting material because of the desirable mechanical properties and resistance to corrosion of stainless steel. Transparent $\mathrm{TiO}_{2}$ films on this substrate have also been shown to be effective for sterilization of $B$. pumilus [78]. In this study, the $\mathrm{TiO}_{2}$-coated stainless steel was shown to have a higher photocatalytic activity than the same coating on glass substrates.

Titania photocatalysts doped with $\mathrm{CuO}$ were coated on surfaces and evaluated for biocidal activity [79]. This investigation also explored the synergistic effect of photocatalysis and toxicity of copper to inactivate bacteriophage T4 and E. coli.

Enhanced photocatalysis using nitrogen-doped $\mathrm{TiO}_{2}$ was also reported for its visible light-induced bactericidal activity against human pathogens [80]. It was proposed in this study that photocatalytic disinfection using visible light can offer a means of continuous disinfection for surfaces constantly in contact with humans, such as door handles and push buttons. Visible light-induced inactivation of E. coli was also studied using titania codoped with nitrogen and sulfur [8184]. This introduces new disinfectant opportunities in public environments, such as public toilets, schools, hospitals, stations, airports, hotels, or public transportation, which are ideal places for the transmission of pathogens $[85,86]$.

Photocatalysis has also been investigated for the inactivation of prions, the infectious agents of a family of transmissible, fatal, neurodegenerative disorders affecting both humans and animals [87]. These prions may be transmitted via ingestion of contaminated food or during medical treatments with contaminated biological materials or surgical tools. The effectiveness of photocatalytic oxidation for inactivating these prions can help to reduce the risk of spread and demonstrates the practical applications of this technology for disinfection of contaminated surfaces and inanimate objects.

Another application of photocatalysis in a hospital setting is for the control of Legionnaire's disease, which is associated to hot water distribution systems containing bacteria of the Legionella species [88]. In laboratory scale studies, it was shown that photocatalytic oxidation using $\mathrm{TiO}_{2} / \mathrm{UV}$ was able to mineralize the cells of four strains of L. pneumophilia serogroup 1 (strain 977, strain 1009, strain 1004, and ATCC 33153) upon prolonged treatment. This implies that the process used might be a viable alternative to the traditional disinfection processes used for the control of Legionella bacteria in hospital hot water systems, such as thermal eradication and hyperchlorination [89].

\section{Pharmaceutical and Food Industry}

Due to the antibacterial applications of $\mathrm{TiO}_{2}$-mediated photooxidation, this process shows promise for the elimination of microorganisms in areas where the use of chemical cleaning agents or biocides is ineffective or is restricted by regulations, for example in the pharmaceutical and food industries [33]. $\mathrm{TiO}_{2}$ is nontoxic and has been approved by the American Food and Drug Administration for use in human food, drugs, cosmetics, and food contact materials [90].

$\mathrm{TiO}_{2}$ powder-coated packaging film was shown to inactivate E. coli (ATCC 11775) in vitro when irradiated with UVA light [90]. Actual tests on cut lettuce stored in a $\mathrm{TiO}_{2}$-coated film bag under such irradiation also showed this method to be effective for the reduction of $E$. coli colonies, indicating that the $\mathrm{TiO}_{2}$ coated film could reduce microbial contamination on the surfaces of solid food products and hence reduce the risk of microbial growth in food packaging. $\mathrm{TiO}_{2}$ photocatalysis has also shown to be effective for the inactivation of other foodborne bacteria such as Salmonella chloraesuis subsp., Vibrio parahaemolyticus, and Listeria monocytogenes [69].

Surface disinfection is also of importance to food processing, as foodborne infections can be caused by the proliferation and resistance to cleaning procedures of pathogenic germs on surfaces of the production equipment in such industries. Studies with E. coli strains (PHL 1273) [91] synthesizing curli, a type of appendage that allows the bacteria to stick to surfaces and form biofilms, were able to inactivate this organism using titania and various types of UV irradiation. In dark events studies, following the bacterial inactivation, no bacterial cultivability was recovered after 48 hours, indicating that the durability of the disinfection was adequate. Nitrogen doping of the titania photocatalyst was also reported in a separate study [92] with the use of visible light to inactivate E. coli and biofilm bacteria. Disinfection of $E$. coli using $\mathrm{TiO}_{2}$-containing paper and UV fluorescent irradiation has also been shown [93]. 


\section{Plant Protection Applications}

Photocatalytic disinfection is potentially very important in the control and inactivation of pathogenic species present in the nutritive solution in circulating hydroponic agricultures [94]. Many plant pathogens can be transmitted by irrigation and recycled waters used in hydroponic agriculture. Conventional bactericidal methods often apply chemical pesticides to disinfect these pathogens, but these are often harmful to animals, humans, and the environment due to their residual toxicity [95]. Photocatalytic disinfection of these plant pathogens using $\mathrm{TiO}_{2}$ may be used as a new tool for plant protection and an alternative to the use of harsh chemicals.

Using $\mathrm{TiO}_{2}$ thin film on a glass substrate and UVA irradiation, Enterobacter cloacae SM1 and Erwinia carotovora subsp. Caratovora ZL1, phytopathogenic enterobacteria that cause basal rot and soft rot in a variety of vegetable crops, were efficiently inactivated [95]. Subsequent studies investigated the effects of doping the titania catalyst with various photosensitive dyes using visible light irradiation [96]. It was shown that the disinfection of the phytopathogenic bacteria causing basal and soft rot could be efficiently carried out under visible light using these doped catalysts.

Solar photocatalytic disinfection using batch process reactors and titania photocatalysts was also shown to be effective for the disinfection of five wild strains of the Fusarium genus (F. equiseti, F. oxysporum, F. anthophilum, $F$. verticilloides, and $F$. solani), a common plant pathogen [97]. In this case, natural solar radiation was used and the photocatalytic solar disinfection was compared to solar-only disinfection for these fungi. The photocatalytic process was found to be faster than the solar-only disinfection in all trials.

The disinfecting ability of titania photocatalyst films was also tested on pathogens of mushroom diseases: Trichoderma harzianum, Cladobotryum varium, Spicellum roseum, and P. tolaasii. The disinfection of these species was confirmed by experiments conducted in mushroom growing rooms under black light irradiation, and subsequently, white light irradiation [98].

\section{Wastewater and Effluents}

The use of photocatalysis for water and wastewater treatment is a topic well documented in the literature, especially with respect to solar photocatalysis [17-21, 99-102]. Due to the ability of photocatalysis to mineralize many organic pollutants, it has been used for remediation of contaminated groundwaters through the use of parabolic solar concentrating type reactors. Photocatalysis has been used in engineering scale for solar photocatalytic treatment of industrial nonbiodegradable persistent chlorinated water contaminants [21], and in field scale for treatment of effluents from a resins factory [103]. This process has also shown to be effective for treatment of wastewaters from a 5-fluororacil (a cancer drug) manufacturing plant [104], distillery wastewater [105], pulp and paper mill wastewater [106], dyehouse wastewater [17], and oilfield produced water [35].
However, the disinfection capabilities of photocatalytic processes have not thoroughly been exploited for treatment of wastewaters. Wastewater reclamation and reuse is of growing importance, especially in areas where the freshwater supply is limited, and so effective disinfection of wastewaters is necessary. Any technical means of sewage reuse is limited by persistent organic pollutants and microorganisms which are not removed by the conventional mechanical and biological treatment train [107]. Additional treatment is therefore necessary before any reuse can take place.

Early work on photocatalytic disinfection of municipal secondary wastewater effluents showed an inactivation of coliform bacteria and Poliovirus $I$ using suspensions of titanium dioxide and fluorescent and sunlight irradiation, respectively [28].

Photocatalysis is also useful for disinfection of sewage containing organisms which are highly resistant to traditional disinfection methods, such as Cryptosporidium parvum [108] and noroviruses [109].

Municipal wastewater effluents from a sewage disposal plant in Hannover, Germany were treated in a slurry $\mathrm{TiO}_{2}$ reactor under UVA irradiation to simultaneously detoxify and disinfect the samples [110]. The photocatalytic treatment was able to diminish the concentration of dissolved organic pollutants (indicated by TOC and COD), and as well inactivate pathogenic microorganisms (indicated by E. coli). A similar result was obtained from studies monitoring Faecal streptococci and total coliforms using slurry $\mathrm{TiO}_{2}$ systems with UVA lamps and solar irradiation, respectively [111].

The investigation of bacterial consortia of $E$. coli and Enterococcus species present in real wastewaters from a biological wastewater treatment plant in Lausanne (Switzerland) [112] indicated that the Enterococcus species are less sensitive to photocatalytic treatment than coliforms and other gramnegative bacteria. Additionally, the effects of temperature, turbidity, and various other physical parameters of the samples on the photocatalytic inactivation of E. coli were investigated [113].

Further research investigates enhanced photocatalysis to improve the efficiency of disinfection of wastewaters for reuse, for example, by the use of titania-activated carbon catalyst mixtures [114], and through the development of nanocrystalline photocatalytic $\mathrm{TiO}_{2}$ membranes [115]. The latter is of particular importance in aeronautical applications, as it combines membrane separation technologies with advanced oxidation technologies to create photocatalytic composite membranes designed for the treatment and reuse of water on long-duration space missions [116].

An inexpensive approach to synthesizing a novel nitrogen-doped $\mathrm{TiO}_{2}$ photocatalyst has also been developed [117], improving the efficiency of visible light-induced disinfection of wastewaters, and introducing a new generation of catalysts for this application.

\section{Drinking Water Disinfection}

Titania photocatalysis has been proven to be effective in the removal of chemical compounds and microbiological 
pathogens from water. A thorough review by Mccullagh et al. [16] of the application of photocatalysis for the removal of biological species in this context examines studies on the disinfection effect of $\mathrm{TiO}_{2}$ suspensions, effect of additives and $\mathrm{pH}$, respectively, on the photocatalytic abilities and disinfection effect of $\mathrm{TiO}_{2}$ thin films, and the effect of electrochemically applied potential on the photobactericidal effect of $\mathrm{TiO}_{2}$ thin films. The current discussion will focus on the various applications of photocatalytic drinking water disinfection.

8.1. Drinking Water Production in Developing Countries. In 2004, it was estimated that about $15 \%$ of the world's population, mostly living in the less-favored regions of the planet, did not have access to enough fresh water to satisfy their daily needs, and this number was expected to double by 2015 [118]. This represents a serious public health issue since waterborne, water-washed, and water-based diseases are associated with lack of improvement in domestic water supply and adequate sanitation [119]. Development of low cost-effective methods for removal of pollutants from water supplies can help alleviate this problem. Especially in rural communities, water disinfection must have sufficiently low operational costs. Alternative technologies to traditional chlorination are now being considered for household use [120].

Solar disinfection (SODIS) is a simple technology that is capable of inactivating many waterborne pathogenic bacteria using the combined effect of solar UVA radiation and temperature [121-124]. This method is low cost and does not produce toxic byproducts, however, limits the volume of water subject to treatment (typically $2 \mathrm{~L}$ per exposed water bottle) and has a disadvantageous long time of process (typically 2 day exposure for complete inactivation) [119].

The combination of sunlight and photocatalyst is a promising option for water treatment in areas with insufficient infrastructure but high yearly sunshine. The use of compound parabolic reactors as an efficient technology to collect and focus diffuse and direct solar radiation onto a transparent pipe containing contaminated water has demonstrated feasibility to disinfect water using $\mathrm{TiO}_{2}$ suspensions [125-127].

The European Union International Cooperation program (INCO) has sponsored initiatives for developing a solar photocatalysis-based cost-effective technology for water decontamination and disinfection in rural areas of developing countries, the SOLWATER and AQUACAT projects, respectively [94]. These projects are aimed at developing a solar reactor to decontaminate and disinfect small volumes of water, and field tests with the final prototypes were carried out to validate operation under real conditions [127].

The final SOLWATER prototype was composed of two tubes containing Alstrohm paper impregnated with titanium dioxide, and two tubes containing a supported photosensitizer [94]. These tubes are placed on a compound parabolic concentrating collector and run in series, where the electricity is provided by a solar panel (Figure 1).

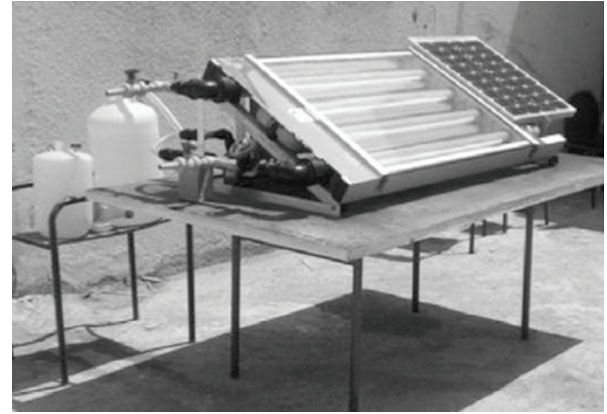

Figure 1: Final SOLWATER and AQUACAT water (solar photocatalytic) disinfection system installed at Ecole Superieure de Technologie de Fez, Morroco [94].

Field tests using the SOLWATER prototype placed the reactor in the yard of a shanty house in Los Pereya, Tucuman, Argentina and studied the removal of bacterial contamination during three months of testing using natural water contaminated with coliforms, E. Faecalis, and $P$. aeruginosa, as well as high levels of natural organic matter and variable inorganic pollutants [127]. The SOLWATER reactor was shown to be effective for this application. Similar tests have been performed in photoreactors installed in various geographic regions, including Egypt, France, Greece, Mexico, Morocco, Peru, Spain, Switzerland, and Tunisia [94].

Other research in the field of potable water production in developing countries includes the development of affordable and efficient technology in the form of batch borosilicate glass and PET plastic SODIS reactors fitter with flexible plastic inserts coated with $\mathrm{TiO}_{2}$ powder [128]. These were shown to be 20 and $25 \%$ more effective, respectively, than SODIS alone for the inactivation of E. coli K12. This novel system was also able to reduce the concentration of Cryptosporidium parvum oocysts present [129]. It should be also noted that there has also been significant research done in the advance of solar disinfection of this highly resistant organism using SODIS alone $[123,130,131]$.

8.2. Surface Water Treatment. While the majority of photocatalytic disinfection studies reported are carried out with distilled water or buffer solutions [16], there have been attempts to quantify the effects of the chemical constituents of natural surface waters on $\mathrm{TiO}_{2}$ photocatalysis $[132,133]$. It has been shown, using surface water samples, that the presence of inorganic ions and humic acids decrease the photocatalytic disinfection rate of E. coli [133].

Other efforts have been made to evaluate photocatalysis applications using real waters [134-138]. For example, the integration of $\mathrm{TiO}_{2}$ photocatalysis into traditional water treatment processes for the removal of organic matter, which has variable levels during the year, was studied in the UK using three surface water samples [136].

Natural water samples from the Cauca River in Cali, Columbia showed drastic E. coli culturable cell concentration increase 24 hours after stopping irradiation [135]. This was not observed for the control experiment using an E. coli 
suspension in distilled water. It was concluded that caution should be taken when making predictions based on simple models as they are not necessarily representative of natural crude water samples.

The effect of $\mathrm{pH}$, inorganic ions, organic matter, and $\mathrm{H}_{2} \mathrm{O}_{2}$ on $E$. coli photocatalytic inactivation by $\mathrm{TiO}_{2}$ was studied by simulating natural and environmental conditions of these parameters using distilled and tap water samples [132]. The results of this study and others [133] confirmed that laboratory results using ultrapure water samples are not representative of the real application in natural waters.

In studies done on surface water samples by Ireland et al. [134], it was concluded that inorganic-radical scavengers can have a major negative impact on the efficacy of the photocatalytic process, and the presence of organic matter in the water samples also degrades the E. coli inactivation kinetics.

Using a field-scale compound parabolic collector at the Swiss Federal Institute of Technology (EPFL), in Lausanne, natural water from the Leman Lake was used to suspend E. coli in the presence of $\mathrm{TiO}_{2}$ and irradiation under solar conditions [126]. From studies on the postirradiation period, the effective disinfection time (EDT) was defined as the time necessary to avoid bacterial regrowth after $24 \mathrm{~h}$ (or $48 \mathrm{~h}$ ) in the dark after stopping phototreatment. It was suggested that the EDT necessary be used as an indicator of the impact of the solar photocatalytic process on bacteria instead of the UV dose required to achieve a certain level of disinfection.

8.3. Eutrophic Water Treatment. Another application of photocatalytic disinfection is in the treatment of eutrophic water. Control of algal blooms in eutrophic water is important because toxic cyanobacterial blooms in drinking water supplies may cause human health problems [137]. Copper-based algaecides can be used to control these blooms, however this method introduces secondary environmental problems [138].

Photocatalytic inactivation of three species of algae: Anabaena, microcystis, and Melosira, was studied using $\mathrm{TiO}_{2}$ coated glass beads and UV-light irradiation [138]. Complete photocatalytic inactivation of Anabaena, microcystis, and Melosira was obtained in about 30 minutes, while the inactivation efficiency for Melosira was somewhat lower due to the inorganic siliceous wall surrounding the cells.

The floating $\mathrm{TiO}_{2}$-coated hollow glass beads were introduced into a mesocosm installed at the Nakdong River, Kimhae, Korea [138]. This mesocosm was a $25 \mathrm{~m}^{2}$ and $2 \mathrm{~m}$ deep semipermeable membrane. The concentrations of chlorophyll-a were measured for one month, and it was shown that more than $50 \%$ of the chlorophyll-a concentration could be reduced using photocatalysts and natural solar radiation. A picture of the experimental mesocosm is depicted in Figure 2.

8.4. Groundwater Treatment. The ability of photocatalysis to break down and detoxify harmful organic chemicals has been exploited for groundwater treatment, as shown by engineering scale demonstrations using solar photocatalysis

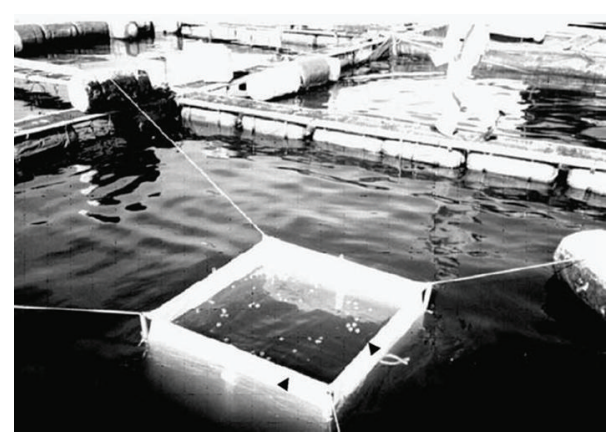

Figure 2: Experimental mesocosm used in Nakdong River, Korea [138].

to remediate groundwater contaminated from leaking underground storage tanks [139].

The disinfecting abilities of photocatalytic processes for application to treating groundwater contaminated with microorganisms such as F. Solani [140] was also investigated and shown to be effective for the removal of such microorganisms. Natural well water containing the F. Solani species and solar illumination and employing CPCs was also explored as a process configuration for this application [141].

\section{Conclusion}

The photocatalytic technique is a versatile and efficient disinfection process capable of inactivating a wide range of harmful microorganisms in various media. It is a safe, nontoxic, and relatively inexpensive disinfection method whose adaptability allows it to be used for many purposes. Research in the field of photocatalytic disinfection is very diverse, covering a broad range of applications.

Particularly, the use of photocatalysis was shown to be effective for various air-cleaning applications to inactivate harmful airborne microbial pathogens, or to combat airborne bioterror threats, such as Anthrax. Photocatalytic thin films on various substrates were also shown to have potential application for "self-disinfecting" surfaces and materials, which can be used for medical implants, "selfdisinfecting" surgical tools and surfaces in laboratory and hospital settings, and equipment in the pharmaceutical and food industries. Photocatalytic food packaging was shown to be a potential way to reduce the risk of foodborne illnesses in cut lettuce and other packaged foods. In terms of plant protection, photocatalysis is being investigated for use in hydroponic agricultures as an alternative to harsh pesticides. For water treatment applications, photocatalytic disinfection has been studied and implemented for drinking water production using novel reactors and solar irradiation. Eutrophic waters containing algal blooms were also shown to be effectively treated using $\mathrm{TiO}_{2}$-coated hollow beads and solar irradiation.

The effectiveness of photocatalytic disinfection for inactivating microorganisms of concern for each of these applications was presented, highlighting key studies and research efforts conducted. While the performance of this technology 
is still to be optimized for the specific applications, based on the literature presented, it is abundantly evident that photocatalysis should be considered as a viable alternative to traditional disinfection methods in some cases.

In a move towards a more environmentally friendly world, traditional solutions to classic problems, such as the production of safe drinking water, must shift towards more sustainable alternatives. Photocatalytic disinfection is not only a replacement technology for traditional methods in traditional applications, but also a novel approach for solving other disinfection problems, such as the control of bioterror threats. In this sense, the strength of photocatalytic disinfection lies in its versatility for use in many different applications.

\section{References}

[1] D. M. Blake, P.-C. Maness, Z. Huang, E. J. Wolfrum, J. Huang, and W. A. Jacoby, "Application of the photocatalytic chemistry of titanium dioxide to disinfection and the killing of cancer cells," Separation and Purification Methods, vol. 28, no. 1, pp. 1-50, 1999.

[2] K. Yogo and M. Ishikawa, "Recent progress in environmental catalytic technology," Catalysis Surveys from Japan, vol. 4, no. 1, pp. 83-90, 2000.

[3] D. Ljubas, "Solar photocatalysis—a possible step in drinking water treatment," Energy, vol. 30, no. 10, pp. 1699-1710, 2005.

[4] H. J. Kool, C. F. Keijl, and J. Hrubec, Water Chlorination: Chemistry, Environmental Impact and Health Effects, Lewis, Chelsia, Mich, USA, 1985.

[5] P. S. M. Dunlop, J. A. Byrne, N. Manga, and B. R. Eggins, "The photocatalytic removal of bacterial pollutants from drinking water," Journal of Photochemistry and Photobiology A, vol. 148, no. 1-3, pp. 355-363, 2002.

[6] F. W. Pontis, Ed., Water Quality and Treatment, A Handbook of Community Water Supplies, Mc-Graw Hill, New York, NY, USA, 4th edition, 1990.

[7] S. Regli, "Disinfection requirements to control for microbial contamination," in Regulating Drinking Water Quality, C. E. Gilbert and E. J. Calabrese, Eds., Lewis, Mich, USA, 1992.

[8] W. J. Masschelin, Ultraviolet Light in Water and Wastewater Sanitation, Lewis, Boca Raton, Fla, USA, 2002.

[9] J. M. C. Robertson, P. K. J. Robertson, and L. A. Lawton, "A comparison of the effectiveness of $\mathrm{TiO}_{2}$ photocatalysis and UVA photolysis for the destruction of three pathogenic micro-organisms," Journal of Photochemistry and Photobiology A, vol. 175, no. 1, pp. 51-56, 2005.

[10] W.-J. Huang, G.-C. Fang, and C.-C. Wang, "The determination and fate of disinfection by-products from ozonation of polluted raw water," Science of the Total Environment, vol. 345, no. 1-3, pp. 261-272, 2005.

[11] M. A. Fox, C. C. Chen, K. Park, and J. N. Younathan, in Organic Transformations in Non-Homogeneous Media, M. A. Fox, Ed., ACS Symposium Series, p. 278, 1985.

[12] A. Fujishima, T. N. Rao, and D. A. Tryk, "Titanium dioxide photocatalysis," Journal of Photochemistry and Photobiology C, vol. 1, no. 1, pp. 1-21, 2000.

[13] A.-G. Rincón and C. Pulgarin, "Use of coaxial photocatalytic reactor (CAPHORE) in the $\mathrm{TiO}_{2}$ photo-assisted treatment of mixed E. coli and Bacillus sp. and bacterial community present in wastewater," Catalysis Today, vol. 101, no. 3-4, pp. 331-344, 2005.

[14] K. Sunada, T. Watanabe, and K. Hashimoto, "Studies on photokilling of bacteria on $\mathrm{TiO}_{2}$ thin film," Journal of Photochemistry and Photobiology A, vol. 156, no. 1-3, pp. 227-233, 2003.

[15] T. Matsunaga, R. Tomoda, T. Nakajima, and H. Wake, "Photoelectrochemical sterilization of microbial cells by semiconductor powders," FEMS Microbiology Letters, vol. 29, no. 1-2, pp. 211-214, 1985.

[16] C. Mccullagh, J. M. C. Robertson, D. W. Bahnemann, and P. K. J. Robertson, "The application of $\mathrm{TiO}_{2}$ photocatalysis for disinfection of water contaminated with pathogenic microorganisms: a review," Research on Chemical Intermediates, vol. 33, no. 3-5, pp. 359-375, 2007.

[17] D. Y. Goswami and D. M. Blake, "Cleaning up with sunshine," Mechanical Engineering, vol. 118, no. 8, pp. 56-59, 1996.

[18] D. Y. Goswami, "A review of engineering developments of aqueous phase solar photocatalytic detoxification and disinfection processes," Journal of Solar Energy Engineering, Transactions of the ASME, vol. 119, no. 2, pp. 101-107, 1997.

[19] M. Romero, J. Blanco, B. Sánchez et al., "Solar photocatalytic degredation of water and air pollutants: challenges and perspectives," Solar Energy, vol. 66, no. 2, pp. 169-182, 1999.

[20] D. Y. Goswami, S. Vijayaraghavan, S. Lu, and G. Tamm, "New and emerging developments in solar energy," Solar Energy, vol. 76, no. 1-3, pp. 33-43, 2004.

[21] S. Malato, J. Blanco, D. C. Alarcón, M. I. Maldonado, P. Fernández-Ibáñez, and W. Gernjak, "Photocatalytic decontamination and disinfection of water with solar collectors," Catalysis Today, vol. 122, no. 1-2, pp. 137-149, 2007.

[22] S. S. Block and D. Y. Goswami, "Chemical enhanced sunlight for killing bacteria," in Proceedings of the ASME International Solar Energy conference, vol. 1, pp. 431-437, 1995.

[23] R. Armon, N. Laot, N. Narkis, and I. Neeman, "Photocatalytic inactivation of different bacteria and bacteriophages in drinking water at different $\mathrm{TiO}_{2}$ concentration with or without exposure to $\mathrm{O}_{2}$," Journal of Advanced Oxidation Technologies, vol. 3, pp. 145-150, 1998.

[24] A. T. Cooper, D. Y. Goswami, and S. S. Block, "Solar photochemical detoxification and disinfection for water treatment in tropical developing countries," Journal of Advanced Oxidation Technologies, vol. 3, no. 2, pp. 151-154, 1998.

[25] M. Biguzzi and G. Shama, "Effect of titanium dioxide concentration on the survival of Pseudomonas stutzeri during irradiation with near ultraviolet light," Letters in Applied Microbiology, vol. 19, no. 6, pp. 458-460, 1994.

[26] H. N. Pham, T. McDowell, and E. Wilkins, "Photocatalytically-mediated disinfection of water using $\mathrm{TiO}_{2}$ as a catalyst and spore-forming Bacillus pumilus as a model," Journal of Environmental Science and Health. Part A, vol. 30, no. 3, pp. 627-636, 1995.

[27] J. C. Sjogren and R. A. Sierka, "Inactivation of phage MS2 by iron-aided titanium dioxide photocatalysis," Applied and Environmental Microbiology, vol. 60, no. 1, pp. 344-347, 1994.

[28] R. J. Watts, S. Kong, M. P. Orr, G. C. Miller, and B. E. Henry, "Photocatalytic inactivation of coliform bacteria and viruses in secondary wastewater effluent," Water Research, vol. 29, no. 1, pp. 95-100, 1995. 
[29] H. Ryu, D. Gerrity, J. C. Crittenden, and M. Abbaszadegan, "Photocatalytic inactivation of Cryptosporidium parvum with $\mathrm{TiO}_{2}$ and low-pressure ultraviolet irradiation," Water Research, vol. 42, no. 6-7, pp. 1523-1530, 2008.

[30] M. Sökmen, S. Deǧerli, and A. Aslan, "Photocatalytic disinfection of Giardia intestinalis and Acanthamoeba castellani cysts in water," Experimental Parasitology, vol. 119, no. 1, pp. 44-48, 2008.

[31] S. M. Karvinen, "The effects of trace element doping on the optical properties and photocatalytic activity of nanostructured titanium dioxide," Industrial and Engineering Chemistry Research, vol. 42, no. 5, pp. 1035-1043, 2003.

[32] A. Vohra, D. Y. Goswami, D. A. Deshpande, and S. S. Block, "Enhanced photocatalytic inactivation of bacterial spores on surfaces in air," Journal of Industrial Microbiology and Biotechnology, vol. 32, no. 8, pp. 364-370, 2005.

[33] E. V. Skorb, L. I. Antonouskaya, N. A. Belyasova, D. G. Shchukin, H. Möhwald, and D. V. Sviridov, "Antibacterial activity of thin-film photocatalysts based on metal-modified $\mathrm{TiO}_{2}$ and $\mathrm{TiO}_{2}: \mathrm{In}_{2} \mathrm{O}_{3}$ nanocomposite," Applied Catalysis $B$, vol. 84, no. 1-2, pp. 94-99, 2008.

[34] J. C. Yu, W. Ho, J. Yu, H. Yip, K. W. Po, and J. Zhao, "Efficient visible-light-induced photocatalytic disinfection on sulfurdoped nanocrystalline titania," Environmental Science and Technology, vol. 39, no. 4, pp. 1175-1179, 2005.

[35] G. Li, T. An, X. Nie et al., "Mutagenicity assessment of produced water during photoelectrocatalytic degradation," Environmental Toxicology and Chemistry, vol. 26, no. 3, pp. 416-423, 2007.

[36] T. P. T. Cushnie, P. K. J. Robertson, S. Officer, P. M. Pollard, C. McCullagh, and J. M. C. Robertson, "Variables to be considered when assessing the photocatalytic destruction of bacterial pathogens," Chemosphere, vol. 74, no. 10, pp. 13741378, 2009.

[37] Y.-S. Choi and B.-W. Kim, "Photocatalytic disinfection of $E$ coli in a UV/TiO ${ }_{2}$-immobilised optical-fibre reactor," Journal of Chemical Technology and Biotechnology, vol. 75, no. 12, pp. 1145-1150, 2000.

[38] M. Subrahmanyam, P. Boule, V. D. Kumari, D. N. Kumar, M. Sancelme, and A. Rachel, "Pumice stone supported titanium dioxide for removal of pathogen in drinking water and recalcitrant in wastewater," Solar Energy, vol. 82, no. 12, pp. 1099-1106, 2008.

[39] C. Guillard, T.-H. Bui, C. Felix, V. Moules, B. Lina, and P. Lejeune, "Microbiological disinfection of water and air by photocatalysis," Comptes Rendus Chimie, vol. 11, no. 1-2, pp. 107-113, 2008.

[40] D. T. Tompkins, W. A. Zeitner, B. J. Lawnicki, and M. A. Anderson, "Evaluation of photocatalysis for gas-phase air cleanin-part 1: process, technical, and sizing considerations," ASHRAE Transactions, vol. 111, no. 2, pp. 60-84, 2005.

[41] D. F. Ollis, "Photocatalytic purification and remediation of contaminated air and water," Comptes Rendus de l'Academie des Sciences IIC 3, vol. 3, no. 6, pp. 405-411, 2000.

[42] W. A. Jacoby, P. C. Maness, E. J. Wolfrum, D. M. Blake, and J. A. Fennell, "Mineralization of bacterial cell mass on a photocatalytic surface in air," Environmental Science and Technology, vol. 32, no. 17, pp. 2650-2653, 1998.

[43] D. Y. Goswami, D. M. Trivedi, and S. S. Block, "Photocatalytic disinfection of indoor air," Journal of Solar Energy Engineering, Transactions of the ASME, vol. 119, no. 1, pp. 92-96, 1997.
[44] D. Y. Goswami, D. M. Trivedi, and S. S. Block, "Photocatalytic disinfection of indoor air," Journal of Solar Energy Engineering, Transactions of the ASME, vol. 119, no. 1, pp. 92-96, 1997.

[45] T. K. Goswami, S. Hingorani, H. Griest, D. Y. Goswami, and S. S. Block, "Photocatalytic system to destroy bioaerosols in air," Journal of Advanced Oxidation Technologies, vol. 4, no. 2, pp. 185-188, 1999.

[46] H. T. Griest, S. K. Hingorani, K. Kelly, and D. Y. Goswami, "Using scanning electron microscopy to visualize the photocatalytic mineralization of airborne microorganisms," in Proceedings of the 9th International Conference on Indoor Air Quality and Climate, Processing of the Indoor Air, pp. 712-717, Monterey, Calif, USA, 2002.

[47] C. Lee, H. Choi, C. Lee, and H. Kim, "Photocatalytic properties of nano-structured $\mathrm{TiO}_{2}$ plasma sprayed coating," Surface and Coatings Technology, vol. 173, no. 2-3, pp. 192200, 2003.

[48] J.-H. Kau, D.-S. Sun, H.-H. Huang, M.-S. Wong, H.C. Lin, and H.-H. Chang, "Role of visible light-activated photocatalyst on the reduction of anthrax spore-induced mortality in mice," PLoS ONE, vol. 4, no. 1, pp. 1-8, 2009.

[49] H. Knight, "Sars wars," Engineer, vol. 292, pp. 27-35, 2003.

[50] D. Mitoraj, A. Jańczyk, M. Strus et al., "Visible light inactivation of bacteria and fungi by modified titanium dioxide," Photochemical and Photobiological Sciences, vol. 6, no. 6, pp. 642-648, 2007.

[51] A. Pal, S. O. Pehkonen, L. E. Yu, and M. B. Ray, "Photocatalytic inactivation of Gram-positive and Gram-negative bacteria using fluorescent light," Journal of Photochemistry and Photobiology A, vol. 186, no. 2-3, pp. 335-341, 2007.

[52] E. J. Wolfrum, J. Huang, D. M. Blake et al., "Photocatalytic oxidation of bacteria, bacterial and fungal spores, and model biofilm components to carbon dioxide on titanium dioxidecoated surfaces," Environmental Science and Technology, vol. 36, no. 15, pp. 3412-3419, 2002.

[53] J. Kiwi and V. Nadtochenko, "New evidence for $\mathrm{TiO}_{2}$ photocatalysis during bilayer lipid peroxidation," Journal of Physical Chemistry B, vol. 108, no. 45, pp. 17675-17684, 2004.

[54] R. Basca, J. Kiwi, T. Ohno, P. Albers, and V. Nadtochenko, "Preparation, testing and characterization of doped $\mathrm{TiO}_{2}$ able to transform biomolecules under visible light irradiation by peroxidation/oxidation," Journal Physical Chemistry B, vol. 109, pp. 5994-6003, 2005.

[55] J. Kiwi and V. Nadtochenko, "Evidence for the mechanism of photocatalytic degradation of the bacterial wall membrane at the $\mathrm{TiO}_{2}$ interface by ATR-FTIR and laser kinetic spectroscopy," Langmuir, vol. 21, no. 10, pp. 4631-4641, 2005.

[56] V. A. Nadtochenko, A. G. Rincon, S. E. Stanca, and J. Kiwi, "Dynamics of E. coli membrane cell peroxidation during $\mathrm{TiO}_{2}$ photocatalysis studied by ATR-FTIR spectroscopy and AFM microscopy," Journal of Photochemistry and Photobiology A, vol. 169, no. 2, pp. 131-137, 2005.

[57] V. Nadtochenko, C. Pulgarin, P. Bowen, and J. Kiwi, "Laser spectroscopy of the interaction of bacterial wall membranes and E. coli with $\mathrm{TiO}_{2}$," Journal of Photochemistry and Photobiology A, vol. 181, pp. 401-404, 2006.

[58] M. P. Paschoalino and W. F. Jardim, "Indoor air disinfection using a polyester supported $\mathrm{TiO}_{2}$ photo-reactor," Indoor Air, vol. 18, no. 6, pp. 473-479, 2008.

[59] V. Krishna, S. Pumprueg, S.-H. Lee et al., "Photocatalytic disinfection with titanium dioxide coated multi-wall carbon nanotubes," Process Safety and Environmental Protection, vol. 83, no. 4 B, pp. 393-397, 2005. 
[60] S. A. Grinshpun, A. Adhikari, T. Honda et al., "Control of aerosol contaminants in indoor air: combining the particle concentration reduction with microbial inactivation," Environmental Science and Technology, vol. 41, no. 2, pp. 606-612, 2007.

[61] A. Pal, X. Mint, L. E. Yu, S. O. Pehkonen, and M. B. Ray, "Photocatalytic inactivation of bioaerosols by $\mathrm{TiO}_{2}$ coated membrane," International Journal of Chemical Reactor Engineering, vol. 3, p. A45, 2005.

[62] T. Yuranova, A. G. Rincon, A. Bozzi et al., "Antibacterial textiles prepared by RF-plasma and vacuum-UV mediated deposition of silver," Journal of Photochemistry and Photobiology A, vol. 161, no. 1, pp. 27-34, 2003.

[63] T. Yuranova, A. G. Rincon, C. Pulgarin, D. Laub, N. Xantopoulos, and H.-J. Mathieu, "Bactericide cotton textiles active in E. coli abatement prepared under mild preparation conditions," Journal of Photochemistry and Photobiology A, vol. 181, pp. 363-369, 2006.

[64] M. I. Mejia, G. Restrepo, J. M. Marin, R. Sanjines, C. Pulgarin, and E. Mielczarski, "Magnetron-sputtered Ag surfaces. New evidence for the nature of the Ag ions intervening in bacterial inactivation," JACS Applied Materials and Interfaces, vol. 2, pp. 230-235, 2010.

[65] M. Paschoalino, N. C. Guedes, W. Jardim, E. Mielczarski, K. Mielczarski, and P. Bowen, "Photo-assisted inactivation of $E$. coli by high surface area $\mathrm{CuO}$ under light irradiation $(>360$ $\mathrm{nm})$," Journal of Photochemistry and Photobiology A, vol. 199, pp. 105-111, 2008.

[66] A. Moncayo-Lasso, R. A. Torres-Palma, J. Kiwi, N. Benítez, and C. Pulgarin, "Bacterial inactivation and organic oxidation via immobilized photo-Fenton reagent on structured silica surfaces," Applied Catalysis B, vol. 84, no. 3-4, pp. 577583,2008

[67] F. Chen, X. Yang, and Q. Wu, "Antifungal capability of $\mathrm{TiO}_{2}$ coated film on moist wood," Building and Environment, vol. 44, no. 5, pp. 1088-1093, 2009.

[68] P. Kern, P. Schwaller, and J. Michler, "Electrolytic deposition of titania films as interference coatings on biomedical implants: microstructure, chemistry and nano-mechanical properties," Thin Solid Films, vol. 494, no. 1-2, pp. 279-286, 2006.

[69] P. Evans and D. W. Sheel, "Photoactive and antibacterial $\mathrm{TiO}_{2}$ thin films on stainless steel," Surface and Coatings Technology, vol. 201, no. 22-23, pp. 9319-9324, 2007.

[70] K. Shiraishi, H. Koseki, T. Tsurumoto et al., "Antibacterial metal implant with a $\mathrm{TiO}_{2}$-conferred photocatalytic bactericidal effect against Staphylococcus aureus," Surface and Interface Analysis, vol. 41, no. 1, pp. 17-22, 2009.

[71] Y. Kubota, T. Shuin, C. Kawasaki et al., "Photokilling of T-24 human bladder cancer cells with titanium dioxide," British Journal of Cancer, vol. 70, no. 6, pp. 1107-1111, 1994.

[72] H. Irie, K. Sunada, and K. Hashimoto, "Recent developments in $\mathrm{TiO}_{2}$ photocatalysis: novel applications to interior ecology materials and energy saving systems," Electrochemistry, vol. 72, no. 12, pp. 807-812, 2004.

[73] S.-H. Lee, S. Pumprueg, B. Moudgil, and W. Sigmund, "Inactivation of bacterial endospores by photocatalytic nanocomposites," Colloids and Surfaces B, vol. 40, no. 2, pp. 93-98, 2005.

[74] K. P. Kühn, I. F. Chaberny, K. Massholder et al., "Disinfection of surfaces by photocatalytic oxidation with titanium dioxide and UVA light," Chemosphere, vol. 53, no. 1, pp. 71-77, 2003.
[75] Y. Kikuchi, K. Sunada, T. Iyoda, K. Hashimoto, and A. Fujishima, "Photocatalytic bactericidal effect of $\mathrm{TiO}_{2}$ thin films: dynamic view of the active oxygen species responsible for the effect," Journal of Photochemistry and Photobiology A, vol. 106, no. 1-3, pp. 51-56, 1997.

[76] P. Evans, T. English, D. Hammond, M. E. Pemble, and D. W. Sheel, "The role of $\mathrm{SiO}_{2}$ barrier layers in determining the structure and photocatalytic activity of $\mathrm{TiO}_{2}$ films deposited on stainless steel," Applied Catalysis A, vol. 321, no. 2, pp. 140-146, 2007.

[77] L. Caballero, K. A. Whitehead, N. S. Allen, and J. Verran, "Inactivation of Escherichia coli on immobilized $\mathrm{TiO}_{2}$ using fluorescent light," Journal of Photochemistry and Photobiology A, vol. 202, no. 2-3, pp. 92-98, 2009.

[78] J. C. Yu, W. Ho, J. Lin, H. Yip, and P. K. Wong, "Photocatalytic activity, antibacterial effect, and photoinduced hydrophilicity of $\mathrm{TiO}_{2}$ films coated on a stainless steel substrate," Environmental Science and Technology, vol. 37, no. 10, pp. 2296-2301, 2003.

[79] K. Sunada, T. Watanabe, and K. Hashimoto, "Bactericidal activity of copper-deposited $\mathrm{TiO}_{2}$ thin film under weak UV light illumination," Environmental Science and Technology, vol. 37, no. 20, pp. 4785-4789, 2003.

[80] M.-S. Wong, W.-C. Chu, D.-S. Sun et al., "Visible-lightinduced bactericidal activity of a nitrogen-doped titanium photocatalyst against human pathogens," Applied and Environmental Microbiology, vol. 72, no. 9, pp. 6111-6116, 2006.

[81] J. A. Rengifo-Herrera, E. Mielczarski, J. Mielczarski, N. C. Castillo, J. Kiwi, and C. Pulgarin, "Escherichia coli inactivation by $\mathrm{N}, \mathrm{S}$ co-doped commercial $\mathrm{TiO}_{2}$ powders under UV and visible light," Applied Catalysis B, vol. 84, no. 3-4, pp. 448-456, 2008.

[82] J. A. Rengifo-Herrera, K. Pierzchała, A. Sienkiewicz, L. Forró, J. Kiwi, and C. Pulgarin, "Abatement of organics and Escherichia coli by N, S co-doped $\mathrm{TiO}_{2}$ under UV and visible light. Implications of the formation of singlet oxygen $\left({ }^{1} \mathrm{O}_{2}\right)$ under visible light," Applied Catalysis B, vol. 88, no. 3-4, pp. 398-406, 2009.

[83] J. A. Rengifo-Herrera, J. Kiwi, and C. Pulgarin, "N, S codoped and N-doped Degussa P-25 powders with visible light response prepared by mechanical mixing of thiourea and urea. Reactivity towards E. coli inactivation and phenol oxidation," Journal of Photochemistry and Photobiology A, vol. 205, no. 2-3, pp. 109-115, 2009.

[84] J. A. Renigo-Herrera, A. Sienkiewicz, L. Forro, J. Kiwi, J. E. Moser, and C. Pulgarin, "New evidence for the nature of the $\mathrm{N}, \mathrm{S}$, co-doped $\mathrm{TiO}_{2}$ sited under visible light leading to $E$. coli inactivation. Catalyst characterization," Journal of Physical Chemistry, vol. 114, pp. 2717-2723, 2010.

[85] B. A. Walther and P. W. Ewald, "Pathogen survival in the external environment and the evolution of virulence," Biological Reviews of the Cambridge Philosophical Society, vol. 79, no. 4, pp. 849-869, 2004.

[86] K.-T. Chen, P.-Y. Chen, R.-B. Tang et al., "Sentinel hospital surveillance for rotavirus diarrhea in Taiwan, 2001-2003," Journal of Infectious Diseases, vol. 192, no. 1, pp. S44-S48, 2005.

[87] N. Laot, N. Narkis, I. Neeman, and R. Armon, “ $\mathrm{TiO}_{2}$ photocatalytic inactivation of selected microorganisms under various conditions: sunlight, intermittent and variable irradiation intensity, CdS supplementation and entrapment of $\mathrm{TiO}_{2}$ into sol-gel," Journal of Advanced Oxidation Technologies, vol. 4, pp. 97-102, 1999. 
[88] Y. W. Cheng, R. C. Y. Chan, and P. K. Wong, "Disinfection of Legionella pneumophila by photocatalytic oxidation," Water Research, vol. 41, no. 4, pp. 842-852, 2007.

[89] Centers for Disease Control and Prevention, Hospital Control Practices Advisory Committee, "Guidelines for prevention of nosocomial pneumonia," CDC's Morbidity and Mortality Weekly Reporter, vol. 46, pp. 1-79, 1997.

[90] C. Chawengkijwanich and Y. Hayata, "Development of $\mathrm{TiO}_{2}$ powder-coated food packaging film and its ability to inactivate Escherichia coli in vitro and in actual tests," International Journal of Food Microbiology, vol. 123, no. 3, pp. 288-292, 2008.

[91] A. K. Benabbou, Z. Derriche, C. Felix, P. Lejeune, and C. Guillard, "Photocatalytic inactivation of Escherischia coli. Effect of concentration of $\mathrm{TiO}_{2}$ and microorganism, nature, and intensity of UV irradiation," Applied Catalysis B, vol. 76, no. 3-4, pp. 257-263, 2007.

[92] Y. Liu, J. Li, X. Qiu, and C. Burda, "Bactericidal activity of nitrogen-doped metal oxide nanocatalysts and the influence of bacterial extracellular polymeric substances (EPS)," Journal of Photochemistry and Photobiology A, vol. 190, no. 1, pp. 94-100, 2007.

[93] H. Matsubara, M. Takada, and S. Koyama, "Research on application of photoactive $\mathrm{TiO}_{2}$ to paper," Kinoshi Kenkyu Kaishi, vol. 34, pp. 36-39, 1996.

[94] J. Blanco, S. Malato, P. Fernández-Ibañez, D. Alarcón, W. Gernjak, and M. I. Maldonado, "Review of feasible solar energy applications to water processes," Renewable and Sustainable Energy Reviews, vol. 13, no. 6-7, pp. 1437-1445, 2009.

[95] K. S. Yao, D. Y. Wang, W. Y. Ho, J. J. Yan, and K. C. Tzeng, "Photocatalytic bactericidal effect of $\mathrm{TiO}_{2}$ thin film on plant pathogens," Surface and Coatings Technology, vol. 201, no. 15, pp. 6886-6888, 2007.

[96] K. S. Yao, D. Y. Wang, C. Y. Chang et al., "Photocatalytic disinfection of phytopathogenic bacteria by dye-sensitized $\mathrm{TiO}_{2}$ thin film activated by visible light," Surface and Coatings Technology, vol. 202, no. 4-7, pp. 1329-1332, 2007.

[97] C. Sichel, M. de Cara, J. Tello, J. Blanco, and P. FernándezIbáñez, "Solar photocatalytic disinfection of agricultural pathogenic fungi: Fusarium species," Applied Catalysis B, vol. 74, no. 1-2, pp. 152-160, 2007.

[98] D. Sawada, M. Ohmasa, M. Fukuda et al., "Disinfection of some pathogens of mushroom cultivation by photocatalytic treatment," Mycoscience, vol. 46, no. 1, pp. 54-60, 2005.

[99] R. Dillert, S. Vollmer, M. Schober et al., "Pilot plant studies on the photocatalytic oxidation of a pretrated industrial wastewater," GWF Wasser Abwasser, vol. 140, no. 4, pp. 293297, 1999.

[100] R. Dillert, S. Vollmer, E. Gross et al., "Solar-catalytic treatment of an industrial wastewater," Zeitschrift fur Physikalische Chemie, vol. 213, no. 2, pp. 141-147, 1999.

[101] R. Dillert, S. Vollmer, M. Schober et al., "Photokatalytische behandlung eines industriabwassers im stegdoppelplattenreaktor," Chemie Ingenieur Tecnik, vol. 71, pp. 396-399, 1999.

[102] D. Bahnemann, "Photocatalytic water treatment: solar energy applications," Solar Energy, vol. 77, no. 5, pp. 445-459, 2004.

[103] J. Blanco and S. Malato, "Solar photocatalytic mineralization of real hazardous waste water at pre-industrial level," in Proceedings of the ASME/JSME/JSES International Solar Energy Conference, D. E. Klett, R. E. Hogan, and T. Tanaka, Eds., pp. 103-109, San Francisco, Calif, USA, 1994.
[104] M. Anhegen, D. Y. Goswami, and G. Svedberg, "Photocatalytic treatment of wastewater from 5-fluoracil manufacturing," in Proceedings of the ASME/JSME/JSES International Solar Energy Conference, Maui, Hawaii, 1995.

[105] A. H. Zaidi, D. Y. Goswami, and A. C. Wilkie, "Solar photocatalytic post-treatment of anaerobically digested distillery effluent," in Proceedings of the American Solar Energy Society Annual Conference, pp. 51-56, Minneapolis, Minn, USA, 1995.

[106] C. S. Turchi, L. Edmunson, and D. F. Ollis, "Application of heterogeneous photocatalysis for the destruction of organic contaminants from a paper mill alkali extraction process," in Proceedings of the TAPPI 5th International Symposium on Wood and Pulping Chemistry, Raleigh, NC, USA, 1989.

[107] O. Seven, B. Dindar, S. Aydemir, D. Metin, M. A. Ozinel, and S. Icli, "Solar photocalytic disinfection of a group of bacteria and fungi aqueous suspensions with $\mathrm{TiO}_{2}, \mathrm{ZnO}$ and sahara desert dust," Journal of Photochemistry and Photobiology A, vol. 165, no. 1-3, pp. 103-107, 2004.

[108] M. Otaki, T. Hirata, and S. Ohgaki, "Aqueous microorganisms inactivation by photocatalytic reaction," Water Science and Technology, vol. 42, no. 3-4, pp. 103-108, 2000.

[109] T. Kato, T. Shibata, H. Tohma, M. Tamura, and O. Miki, "Degredation of norovirus in sewage treatment water by photocatalytic ultraviolent disinfection," Nippon Steel Technical Report, pp. 41-44, 92.

[110] R. Dillert, U. Siemon, and D. Bahnemann, "Photocatalytic disinfection of municipal wastewater," Chemical Engineering and Technology, vol. 21, no. 4, pp. 356-358, 1998.

[111] J. A. Herrera Melián, J. M. Doña Rodríguez, A. Viera Suárez et al., "The photocatalytic disinfection of urban waste waters," Chemosphere, vol. 41, no. 3, pp. 323-327, 2000.

[112] A.-G. Rincón and C. Pulgarin, "Bactericidal action of illuminated $\mathrm{TiO}_{2}$ on pure Escherichia coli and natural bacterial consortia: post-irradiation events in the dark and assessment of the effective disinfection time," Applied Catalysis B, vol. 49, no. 2, pp. 99-112, 2004.

[113] A. G. Rincón and C. Pulgarin, "Photocatalytical inactivation of E. coli: effect of (continuous-intermittent) light intensity and of (suspended-fixed) $\mathrm{TiO}_{2}$ concentration," Applied Catalysis B, vol. 44, no. 3, pp. 263-284, 2003.

[114] Y. LI, M. Ma, X. Wang, and X. Wang, "Inactivated properties of activated carbon-supported $\mathrm{TiO}_{2}$ nanoparticles for bacteria and kinetic study," Journal of Environmental Sciences, vol. 20, no. 12, pp. 1527-1533, 2008.

[115] H. Choi, A. C. Sofranko, and D. D. Dionysiou, "Nanocrystalline $\mathrm{TiO}_{2}$ photocatalytic membranes with a hierarchical mesoporous multilayer structure: synthesis, characterization, and multifunction," Advanced Functional Materials, vol. 16, no. 8, pp. 1067-1074, 2006.

[116] H. Choi, E. Stathatos, and D. D. Dionysiou, "Photocatalytic $\mathrm{TiO}_{2}$ films and membranes for the development of efficient wastewater treatment and reuse systems," Desalination, vol. 202, no. 1-3, pp. 199-206, 2007.

[117] Y. Liu, J. Li, X. Qiu, and C. Burda, "Novel $\mathrm{TiO}_{2}$ nanocatalysts for wastewater purification: tapping energy from the sun," Water Science and Technology, vol. 54, no. 8, pp. 47-54, 2006.

[118] P. H. Gleick, World's Water 2004-2005, Island Press, Washington, DC, USA, 2004.

[119] L. Villen, F. Manjon, D. Garcia-Fresnadillo, and G. Orellana, "Solar water disinfection by photocatalytic singlet oxygen production in heterogenous medium," Applied Catalysis B, vol. 69, pp. 1-9, 2006. 
[120] I. Najm and R. R. Trussel, "New and emerging drinking water treatment technologies," in Identifying Future Drinking Water Contaminants, p. 220, National Academy, Washington, DC, USA, 1999.

[121] M. Boyle, C. Sichel, P. Fernández-Ibáñez et al., "Bactericidal effect of solar water disinfection under real sunlight conditions," Applied and Environmental Microbiology, vol. 74, no. 10, pp. 2997-3001, 2008.

[122] E. Ubomba-Jaswa, C. Navntoft, I. Polo-López, P. FernándezIbáñez, and K. G. McGuigan, "Solar disinfection of drinking water (SODIS): an investigation of the effect of UVA dose on inactivation efficiency," Photochemistry and Photobiological Sciences, vol. 8, no. 5, pp. 587-595, 2009.

[123] H. Gómez-Couso, M. Fontán-Saínz, C. Sichel, P. FernándezIbáñez, and E. Ares-Mazás, "Solar disinfection of turbid waters experimentally contaminated with Cryptosporidium parvum oocysts under real field conditions," Tropical Medicineand International Health, vol. 14, no. 6, pp. 1-9, 2009.

[124] E. Ubomba-Jaswa, P. Fernández-Ibáñez, C. Navntoft, M. Inmaculada Polo-Lópezb, and K. G. McGuigana, "Investigating the microbial inactivation efficiency of a $25 \mathrm{~L}$ batch solar disinfection (SODIS) reactor enhanced with a compound parabolic collector (CPC) for household use," Journal of Chemical Technology and Biotechnology, vol. 85, no. 8, pp. 1028-1037, 2010.

[125] O. A. McLoughlin, P. Fernández-Ibáñez, W. Gernjak, S. Malato Rodriguez, and L. W. Gill, "Photocatalytic disinfection of water using low cost compound parabolic collectors," Solar Energy, vol. 77, no. 5, pp. 625-633, 2004.

[126] A.-G. Rincón and C. Pulgarin, "Field solar E. coli inactivation in the absence and presence of $\mathrm{TiO}_{2}$ : is UV solar dose an appropriate parameter for standardization of water solar disinfection?" Solar Energy, vol. 77, no. 5, pp. 635-648, 2004.

[127] C. Navntoft, P. Araujo, M. I. Litter et al., "Field tests of the solar water detoxification SOLWATER reactor in Los Pereyra, Tucumán, Argentina," Journal of Solar Energy Engineering, Transactions of the ASME, vol. 129, no. 1, pp. 127-134, 2007.

[128] E. F. Duffy, F. Al Touati, S. C. Kehoe et al., "A novel $\mathrm{TiO}_{2}$-assisted solar photocatalytic batch-process disinfection reactor for the treatment of biological and chemical contaminants in domestic drinking water in developing countries," Solar Energy, vol. 77, no. 5, pp. 649-655, 2004.

[129] F. Méndez-Hermida, E. Ares-Mazás, K. G. McGuigan, M. Boyle, C. Sichel, and P. Fernández-Ibáñez, "Disinfection of drinking water contaminated with Cryptosporidium parvum oocysts under natural sunlight and using the photocatalyst $\mathrm{TiO}_{2}$," Journal of Photochemistry and Photobiology B, vol. 88, no. 2-3, pp. 105-111, 2007.

[130] H. Gómez-Couso, M. Fontán-Sainz, J. Fernández-Alonso, and E. Ares-Mazás, "Excystation of Cryptosporidium parvum at temperatures that are reached during solar water disinfection," Parasitology, vol. 136, no. 4, pp. 393-399, 2009.

[131] K. G. McGuigan, F. Méndez-Hermida, J. A. Castro-Hermida et al., "Batch solar disinfection inactivates oocysts of Cryptosporidium parvum and cysts of Giardia muris in drinking water," Journal of Applied Microbiology, vol. 101, no. 2, pp. 453-463, 2006.

[132] A.-G. Rincón and C. Pulgarin, "Effect of pH, inorganic ions, organic matter and $\mathrm{H} 2 \mathrm{O} 2$ on E. coli $\mathrm{K} 12$ photocatalytic inactivation by $\mathrm{TiO}_{2}$ : implications in solar water disinfection," Applied Catalysis B, vol. 51, no. 4, pp. 283-302, 2004.
[133] J. Marugán, R. van Grieken, C. Sordo, and C. Cruz, "Kinetics of the photocatalytic disinfection of Escherichia coli suspensions," Applied Catalysis B, vol. 82, no. 1-2, pp. 27-36, 2008.

[134] J. C. Ireland, P. Klostermann, E. W. Rice, and R. M. Clark, "Inactivation of Escherichia coli by titanium dioxide photocatalytic oxidation," Applied and Environmental Microbiology, vol. 59, no. 5, pp. 1668-1670, 1993.

[135] J. Wist, J. Sanabria, C. Dierolf, W. Torres, and C. Pulgarin, "Evaluation of photocatalytic disinfection of crude water for drinking-water production," Journal of Photochemistry and Photobiology A, vol. 147, no. 3, pp. 241-246, 2002.

[136] C. A. Murray, E. H. Goslan, and S. A. Parsons, " $\mathrm{TiO}_{2} / \mathrm{UV}$ : single stage drinking water treatment for NOM removal?" Journal of Environmental Engineering and Science, vol. 6, no. 3, pp. 311-317, 2007.

[137] S.-C. Kim and D.-K. Lee, "Inactivation of algal blooms in eutrophic water of drinking water supplies with the photocatalysis of $\mathrm{TiO}_{2}$ thin film on hollow glass beads," Water Science and Technology, vol. 52, no. 9, pp. 145-152, 2005.

[138] A. J. Feitz, T. D. Waite, G. J. Jones, B. H. Boyden, and P. T. Orr, "Photocatalytic degredation of the blue-green algal toxin Microcystin-LR in a natural organic-aqueous matrix," Environmental Science and Technology, vol. 33, no. 2, pp. 243249, 1999.

[139] D. Y. Goswami, J. Klausner, G. D. Mathur et al., "Solar photocatalytic treatment of groundwater at Tyndall AFB, field test results," in Proceedings of the American Solar Energy Society Annual Conference, Washington, DC, USA, 1993.

[140] P. Fernández-Ibáñez, C. Sichel, M. I. Polo-López, M. de Cara-García, and J. C. Tello, "Photocatalytic disinfection of natural well water contaminated by Fusarium solani using $\mathrm{TiO}_{2}$ slurry in solar CPC photo-reactors," Catalysis Today, vol. 144, no. 1-2, pp. 62-68, 2009.

[141] M. I. Polo-López, P. Fernández-Ibáñez, I. García-Fernández, I. Oller, I. Salgado-Tránsito, and C. Sichel, "Resistance of Fusarium sp spores to solar $\mathrm{TiO}_{2}$ photocatalysis: influence of spore type and water (scaling-up results)," Journal of Chemical Technology and Biotechnology, vol. 85, pp. 10381048, 2010. 


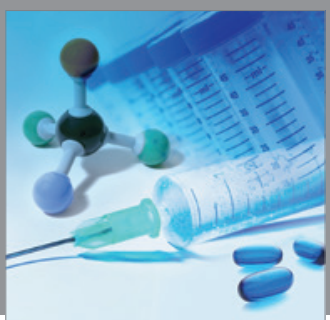

International Journal of

Medicinal Chemistry

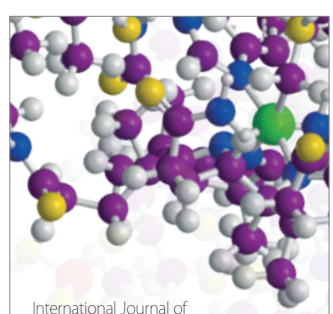

Carbohydrate Chemistry

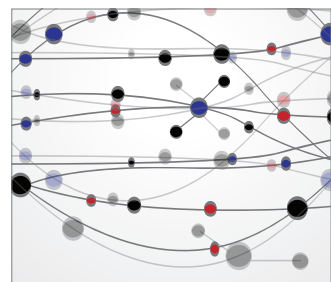

The Scientific World Journal
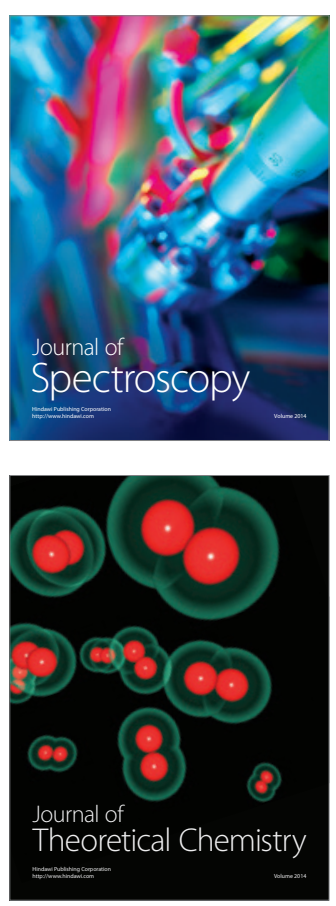
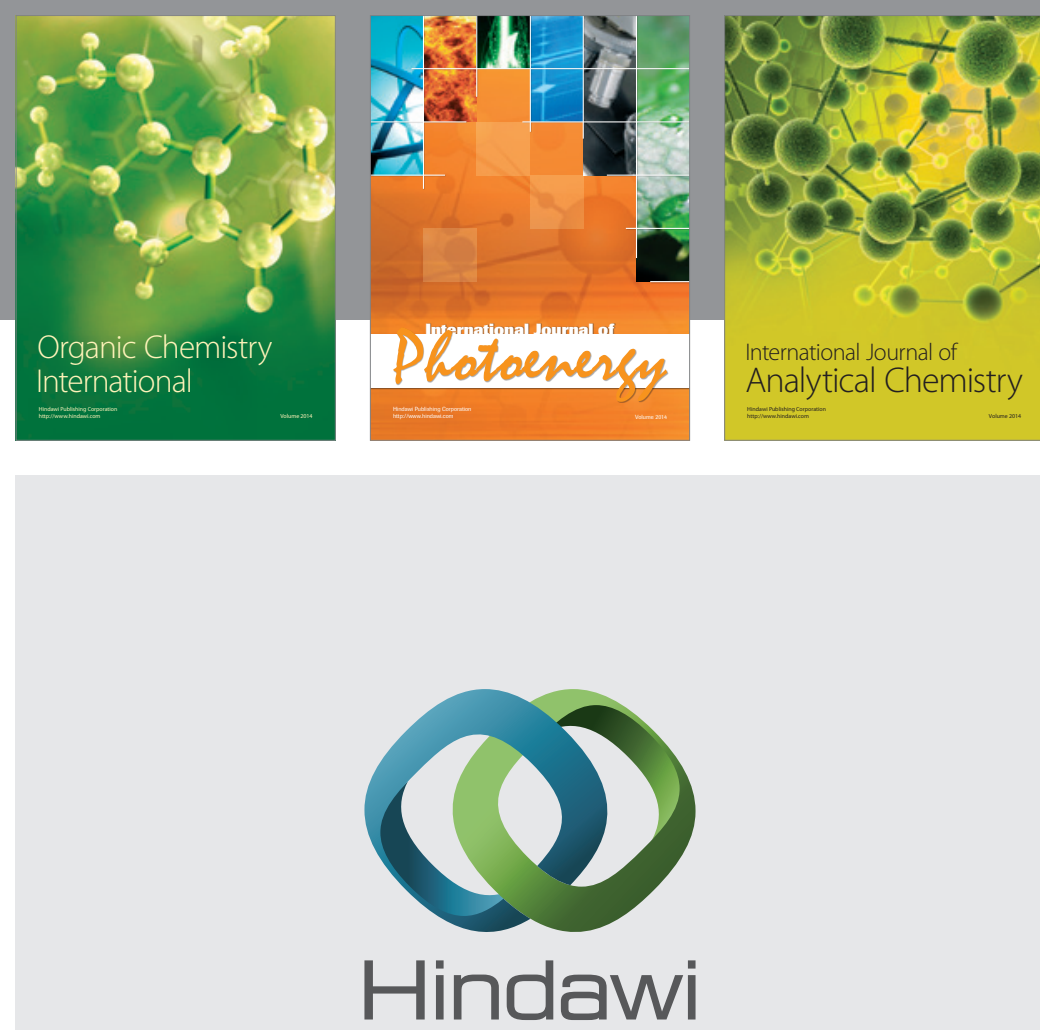

Submit your manuscripts at

http://www.hindawi.com
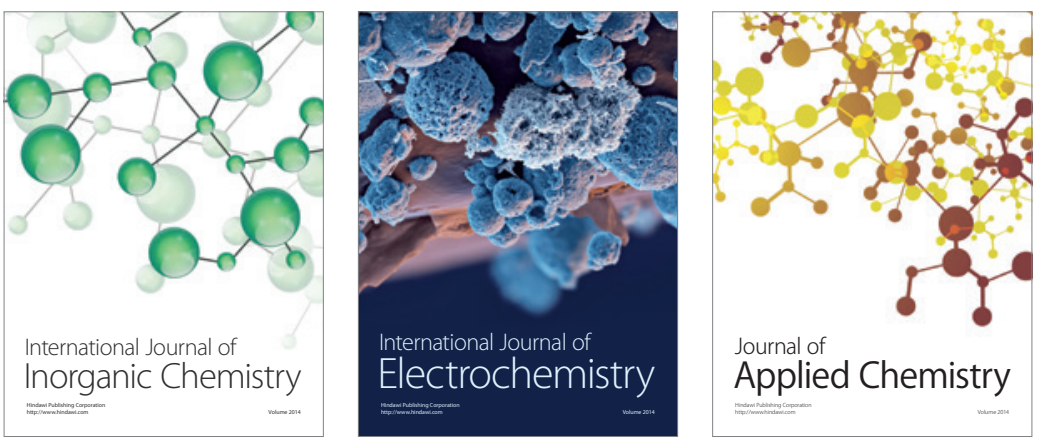

Journal of

Applied Chemistry
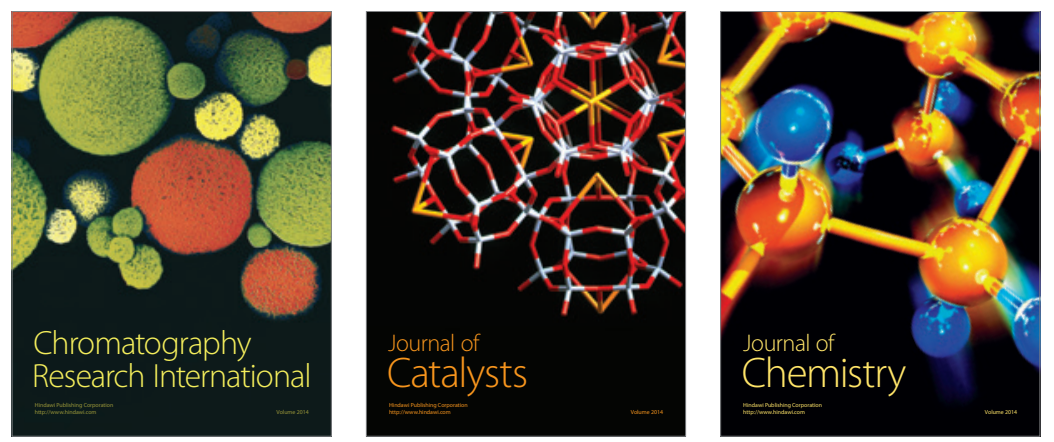
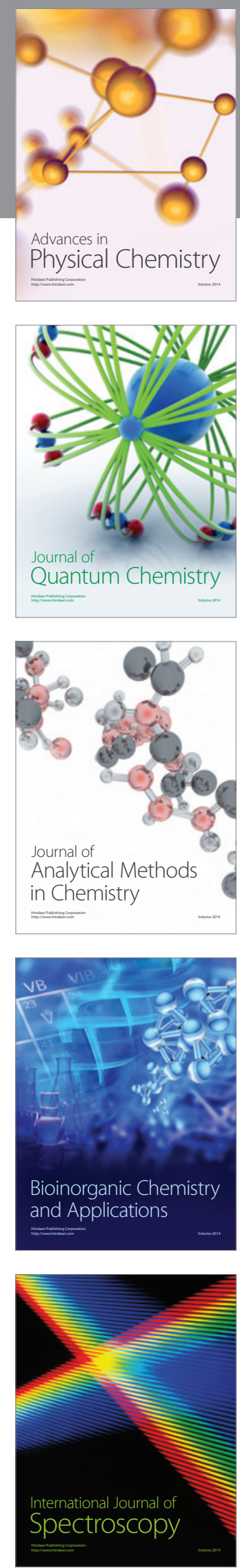